\title{
Measurement of the Human Development Index Inequality
}

\author{
Sigit Haryadi; Westi Riani \\ Institut Teknologi Bandung \\ March 2018
}

Paper DOI 10.17605/OSF.1O/5R42M

\begin{abstract}
This paper proposes a method of measuring the level of inequality of the Human Development Index in a country, using a formula made in April 2016, by Sigit Haryadi, and named as "Haryadi Index". This method is very important because by knowing the imbalance of HDI (Human Development Index) in a country, the government should make a policy to overcome the imbalance, where the HDI inequality is unconsciously is a negative multiplier effect, for example, there is an imbalance between big city and the small town around it, it will encourage people in small towns to migrate to big city, which will make the burden for big cities and reduce the productivity of small towns.
\end{abstract}

\section{Internet Calculator}

To facilitate the calculation, an internet calculator will be created, i.e. a website that provides a field of content, where we are required to fill in the HDI of all provinces in a country or HDI cities in a province, the calculator will provide: (a) Index inequality of HDI in a country or a province, (b) the level of HDI inequality in a country or a province.

The website address is http://sigitharyadi.net/multidicipline/human-development-indexinequality/.

\section{Calculation Method Explanation}

The calculation is done as follows:

a) Calculates the share of the HDI of each city (on the measurement of an HDI inequality of a province) or HDI of each province (on the measurement of a country's HDI imbalance): $\mathrm{Si}=$ (the HDI of a province divided by the total of the IPM of all provinces) or $=$ the HDI of a city divided by the total number of HDI in all provinces in the province.

b) Calculates the inequality of Human Development Index uses the following formula:

$$
H D I \text { Inequality }=1-\frac{1}{N\left\{\sum_{i>j}^{N} S_{i}^{2}+\sum_{i=1}^{N} \sum_{j=1}^{N}\left(S_{i}-S_{j}\right)^{2}\right\}}
$$


c) Then determines the level of imbalance HDI as follows:

i. The index of inequality less than 0.005 is corresponding to the very small Human Development Index Inequality Rate.

ii. The index of inequality between 0.005 to 0.025 is corresponding to the Low Inequality Rate.

iii. The index of inequality between 0.025 to 0.05 is corresponding to the Moderate Inequality Rate.

iv. The index of inequality between 0.05 to 0.15 is corresponding to the High Inequality Rate.

v. The inequality index greater than 0.15 is corresponding to the Very High Human Development Index Inequality Rate.

\section{Note}

In order to better understand the Haryadi Index which is the spirit on the calculation of Human Development Index inequality level, please read the books and papers on the reference, but it is worth noting that the formula used to calculate the level of inequality is one minus the Haryadi Index, because the Haryadi Index is an equality index.

\section{References}

[1] Sigit Haryadi. (2017). Haryadi Index and Its Applications in Science of Law, Sociology, Economics, Statistics, and Telecommunications. Penerbit Elex Media Komputindo. Jakarta. ISBN: 978-602-02-9895-5.

[2] Sigit Haryadi. (2017). Indeks Haryadi dan Penerapan di Ilmu Hukum, Sosiologi, Ekonomi, Statistik, dan Telekomunikasi. Penerbit Elex Media Komputindo, Jakarta. ISBN: 978-602-02-9896-2

[3] Sigit Haryadi. (2016). Haryadi Index for Competition, Equality and Correlation Evaluation. Penerbit Lantip Safari Media, Bandung, Indonesia. ISBN: 978-602-732313-2

[4] Sigit Haryadi. (2016). Haryadi Index untuk Evaluasi Kompetisi, Kesetaraan dan Korelasi. Penerbit Lantip Safari Media, Bandung, Indonesia. ISBN: 978-602-73231-31

[5] Sigit Haryadi. (March 17, 2018). The Six 100-year-old Formula Should be Replaced. Researchgate. DOI 10.13140/RG.2.2.21919.66723

[6] Haryadi, S. (2018, March 17). Sepuluh Implementasi Yang Pertama untuk Membuktikan bahwa "The Harmony in Gradation" adalah "The Formula Everything". Retrieved from osf.io/preprints/inarxiv/ja9ve

[7] Haryadi, S. (2018, March 17). The Ten First Implementations to prove that "The Harmony in Gradation" is "The Formula Everything". Retrieved from osf.io/preprints/inarxiv/59szb

[8] Haryadi, S., \& California, S. H. (2018, March 14). New Method to Calculate the Level of Consistency of the Pauli \& Kraepelin Tests. Retrieved from osf.io/preprints/inarxiv/ty326 
[9] Haryadi, S., \& California, S. H. (2018, March 14). Metoda Baru Untuk Menghitung Tingkat Konsistensi pada Tes Pauli \& Kraepelin. Retrieved from osf.io/preprints/inarxiv/qht8j

[10] Haryadi, S. (2018, March 6). Calculation the Equity Level of an Internet Service. Retrieved from osf.io/uzcmq

[11] Haryadi, S. (2018, March 6). Perhitungan Tingkat Pemerataan Layanan Internet. Retrieved from osf.io/preprints/inarxiv/rgct3

[12] Dyah Rakhma Ariyanti; Sigit Haryadi. (October 2017). Analysis of Harmony In Gradation Index on 5G Cellular Network Quantitative Analysis. The 11th International Conference on Telecommunication Systems, Services, and Applications, At Lombok, Indonesia.

[13] Haryadi, S. (2017, November). Probabilitas Statistik Untuk Insinyur. Researchgate. DOI: $10.13140 /$ RG.2.2.14304.58885

[14] Haryadi, S. (2018, February 1). Indeks Haryadi dan Prospeknya Untuk Menjadi Suatu "Formula of Everything (versi 31 Desember 2017). Retrieved from osf.io/zex45

[15] Haryadi, S. (2018, February 1). KALKULATOR untuk membuat Regresi Linier Tanpa Intersep. Retrieved from osf.io/emvs7

[16] Haryadi, S. (2018, February 1). Kalkulator Untuk Mengukur Tingkat Kompetisi di suatu Industri, dengan menggunakan rumus Indeks Haryadi. Retrieved from osf.io/fy7zu

[17] Haryadi, S. (2018, February 17). Calculation the Competition Levels between Students in Class and the Relation to the Teacher or Lecture Fairness in Teaching. Researchgate. DOI: $10.13140 /$ RG.2.2.30359.06569

[18] Haryadi, S. (2018, February 17). Perhitungan Tingkat Kompetisi antar Murid atau Mahasiswa di Kelas dan Kaitannya Dengan Keadilan Guru atau Dosen Dalam Mengajar. Retrieved from osf.io/a894w

[19] Haryadi, S. (2018, February 22). Equality Correlation Calculation. Researchgate. DOI: 10.13140/RG.2.2.22068.76168

[20] Haryadi, S. (2018, February 22). Kalkulator Untuk Menghitung Korelasi Kesetaraan. Retrieved from osf.io/preprints/inarxiv/7r9jy

[21] Haryadi, S. (2018, February 24). Calculation of "Channel Cavity" on Data Communications. Equality Correlation Calculation. Research gate. DOI: 10.13140/RG.2.2.30536.01288

[22] Haryadi, S. (2018, February 24). Perhitungan "Rongga Kanal” pada Komunikasi Data. Retrieved from osf.io/preprints/inarxiv/y3wcg

[23] Haryadi, S. (2018, February 28). Ikhtisar Organisasi Regulasi Telekomunikasi. Retrieved from osf.io/preprints/inarxiv/g9m3k

[24] Haryadi, S. (2018, February 7). Statistik Terapan: Pengujian Regulasi \& Kebijakan Telekomunikasi. Retrieved from osf.io/3pkfw

[25] Haryadi, S. (2018, January 25). Chapter 1. The Concept of Telecommunication Network Performance and Quality of Service. Retrieved from osf.io/mukqb

[26] Haryadi, S. (2018, January 26). Chapter 2 of Network Performance and Quality of Service: Determination of Key Performance Indicator (KPI). Retrieved from osf.io/preprints/inarxiv/6gtnd

[27] Haryadi, S. (2018, January 26). Chapter 3 of Network Performance and Quality of Service: Technical Measurement of a Mobile Network Performance and Quality of Service. Retrieved from osf.io/q4wsz

[28] Haryadi, S. (2018, January 30). Basic Calculation of the Network's Availability and Reliability (Chapter 4 of Network Performance and Quality of Service). Retrieved from osf.io/preprints/inarxiv/z5mwq 
[29] Haryadi, S. (2018, March 1). Kebijakan Lisensi Telekomunikasi. Retrieved from osf.io/7wbjf

[30] Haryadi, S. (2018, March 5). Performance Measurement of Internet Service. Retrieved from osf.io/9nsw3

[31] Haryadi, S., \& Riani, W. (2018, March 5). METODE PENETAPAN TARIF PAJAK PENGHASILAN YANG BERKEADILAN. Retrieved from osf.io/preprints/inarxiv/ayg58

[32] Nie Levin Kusuma Adiatma ; Sigit Haryadi. (2017, October). Comparison of the Haryadi Index with Existing Method in Competition, Equality, Fairness, and Correlation Level Calculation Case Study: Telecommunication Industry. The 11th International Conference on Telecommunication Systems, Services, and Applications, At Lombok, Indonesia.

[33] Sigit Haryadi. (2017). Calculation of the Mobile Communication Competition using Haryadi Index. DOI: 10.13140/RG.2.2.15634.25280

[34] Sigit Haryadi. (2017). Harmony in Gradation and and its prospects as the Formula of Everything (First edition of posts: December 31, 2017). Researchgate. DOI: 10.13140/RG.2.2.19309.08169

[35] Sigit Haryadi. (2017). the Equality Correlation Method. Researchgate. DOI: 10.13140/RG.2.2.10443.80169.

[36] Sigit Haryadi. (2017). The Non-Intercept Linear Regression Method. Researchgate. DOI: 10.13140/RG.2.2.18721.71522

[37] Sigit Haryadi. (2017). The Fairness over Inequality Index: Unfairness is Disaster - a notebook of Sigit Haryadi. Researchgate. DOI: 10.13140/RG.2.2.34379.49449.

[38] Sigit Haryadi. (2017, December). Calculator for Measurement the Competition Index \& Level. Researchgate. DOI: 10.13140/RG.2.2.23626.26568

[39] Sigit Haryadi. (2017, December). Calculator for non intercept linear regression. Researchgate. DOI: 10.13140/RG.2.2.15761.94562.

[40] Sigit Haryadi. (2017, January). Calculation of the Income Equality Levels between Regions using the Haryadi Index. Researchgate. DOI: 10.13140/RG.2.2.36605.77282

[41] Sigit Haryadi. (2018, February). Applied Statistics for Assessment of the Regulation and Policy: case study in Telecommunication Industry. DOI: 10.13140/RG.2.2.15774.02884

[42] Sigit Haryadi; Dyah Rakhma Ariyanti. (October 2017). The Fairness of Resource Allocation and Its Impact on 5G Ultra-Dense Cellular Network Performance. The 11th International Conference on Telecommunication Systems, Services, and Applications, At Lombok, Indonesia.

[43] Westi Riani; Sigit Haryadi. (2017). CALCULATOR for the Government to make the Fair Policy of Tax Rates. Researchgate. DOI: 10.13140/RG.2.2.18550.50246. Available online at http://sigitharyadi.net/multidicipline/income-tax-rates-calculator$\underline{\mathrm{id} /}$

[44] Westi Riani; Sigit Haryadi. (2017). The Method Of Tax Rate Determination Based On Fairness. Prosiding Seminar Nasional SNaPP2017, Bandung, Indonesia.

[45] Haryadi, S., \& Riani, W. (2018, March 12). Telecommunication Competition and Interconnection. Retrieved from osf.io/preprints/inarxiv/7tfqd

[46] Westi Riani; Sigit Haryadi. (2017). Prosiding SNaPP2017 "THE METHOD OF TAX RATE DETERMINATION BASED ON FAIRNESS". Conference: Seminar Nasional Penelitian dan PKM (SNaPP) 2017At: Bandung, Indonesia.

[47] Sigit Haryadi. (2017). Tantangan Untuk Menerapkan Haryadi Index pada Ilmu Fisika. Jurnal Pendidikan Fisika Sekolah Menengah. Jurnal Pendidikan Fisika Sekolah 
Menengah. Vol 9 no 1 2017. ISSN: 1979-4959. Available at : https://www.researchgate.net/publication/316683866

[48] Westi Riani; Sigit Haryadi. (2016). Keterbatasan Indeks Gini sebagai Ukuran Ketimpangan Pendapatan dan Solusi Metoda Alternatif. Prosiding SNaPP: Sosial, Ekonomi, dan Humaniora.

[49] Haryadi, S., \& Riani, W. (2018, March 19). Pengukuran Ketimpangan Indeks Pembangunan Manusia. Retrieved from osf.io/preprints/inarxiv/x9vjt 